\title{
Atmospheric acidification of mineral aerosols: a source of bioavailable phosphorus for the oceans
}

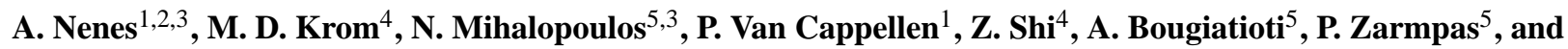 \\ B. Herut ${ }^{6}$ \\ ${ }^{1}$ School of Earth and Atmospheric Sciences, Georgia Institute of Technology, Atlanta, Georgia, USA \\ ${ }^{2}$ School of Chemical and Biomolecular Engineering, Georgia Institute of Technology, Atlanta, Georgia, USA \\ ${ }^{3}$ Institute of Chemical Engineering and High Temperature Chemical Processes, Foundation for Research and Technology \\ Hellas, Patras, Greece \\ ${ }^{4}$ Earth and Biosphere Institute, School of Earth and Environment, University of Leeds, Leeds, UK \\ ${ }^{5}$ Department of Chemistry, University of Crete, Heraklion, Crete, Greece \\ ${ }^{6}$ Israel Oceanographic Limnological Research, Tel Shikmona, Haifa, Israel
}

Received: 11 February 2011 - Published in Atmos. Chem. Phys. Discuss.: 21 February 2011

Revised: 14 May 2011 - Accepted: 27 May 2011 - Published: 1 July 2011

\begin{abstract}
Primary productivity of continental and marine ecosystems is often limited or co-limited by phosphorus. Deposition of atmospheric aerosols provides the major external source of phosphorus to marine surface waters. However, only a fraction of deposited aerosol phosphorus is water soluble and available for uptake by phytoplankton. We propose that atmospheric acidification of aerosols is a prime mechanism producing soluble phosphorus from soil-derived minerals. Acid mobilization is expected to be pronounced where polluted and dust-laden air masses mix. Our hypothesis is supported by the soluble compositions and reconstructed $\mathrm{pH}$ values for atmospheric particulate matter samples collected over a 5-yr period at Finokalia, Crete. In addition, at least tenfold increase in soluble phosphorus was observed when Saharan soil and dust were acidified in laboratory experiments which simulate atmospheric conditions. Aerosol acidification links bioavailable phosphorus supply to anthropogenic and natural acidic gas emissions, and may be a key regulator of ocean biogeochemistry.
\end{abstract}

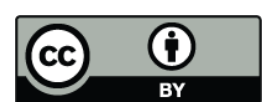

Correspondence to: A. Nenes (athanasios.nenes@gatech.edu)

\section{Introduction}

Primary productivity of continental and marine ecosystems is often limited or co-limited by phosphorus (Howarth, 1988; Elser, 2007). Because riverine inputs of phosphorus (P) preferentially accumulate along the continental margins, airborne sources of $\mathrm{P}$ are particularly important for supporting primary production in oligotrophic areas of the open ocean (Paytan and McLaughlin, 2007). Similar to the nutrient elements iron and silicon, most $\mathrm{P}$ in the atmosphere is associated with particulate matter, primarily mineral aerosols (Mahowald et al., 2008). The major forms of $\mathrm{P}$ in soil-derived dust are minerals from the apatite group and, to a lesser extent, $\mathrm{P}$ bound to iron (hydr)oxide minerals (Singer et al., 2004; Eijsink et al., 2000). These minerals are highly insoluble under the alkaline and oxygenated conditions encountered in oceanic surface waters (Atlas and Pytkowicz, 1977). Combined with the short transit times of mineral aerosols through the photic zone, this implies that the main source of bioavailable $\mathrm{P}$ in atmospheric deposition is water soluble $\mathrm{P}$ produced during airborne processing of soil-derived dust. Mahowald et al. (2008) estimate that globally about $17 \%$ of total atmospheric P deposited at the sea surface is water soluble. The soluble fraction, however, is highly variable, with values ranging between 7 and $100 \%$ (Mahowald et al., 2008). Baker et al. (2006) observed a gradient in soluble $P$ in dust advected off the coast of North Africa. Mahowald et

Published by Copernicus Publications on behalf of the European Geosciences Union. 
al. (2008) further note that it is not known at present what processes control the amount of soluble $\mathrm{P}$ in aerosols.

We hypothesize that acid processing of mineral aerosols is a major pathway for the production of water soluble $\mathrm{P}$ in the atmosphere. The main acids in the atmosphere, $\mathrm{H}_{2} \mathrm{SO}_{4}$ and $\mathrm{HNO}_{3}$, are generated by the oxidation of sulfur and nitrogen gases emitted by biogenic, volcanic and anthropogenic sources (Seinfeld and Pandis, 2006). These acids, if present in sufficient amounts in mineral aerosols, will overcome the available carbonate buffer capacity. This causes aerosol $\mathrm{pH}$ to drop to low values under clear-sky conditions (Meskhidze et al., 2003), increasing the solubilities of apatite and iron (hydr)oxide minerals by several orders of magnitude (Stumm and Morgan, 1996). Production of soluble P is analogous to that invoked to explain the presence of soluble iron and trace metals in atmospheric dust (Meskhidze et al., 2003; Spokes et al., 1994).

\section{Evidence of acid mobilization of $\mathbf{P}$ in Eastern Mediterranean aerosol}

The Eastern Mediterranean Sea (EMS) offers an ideal setting for testing the hypothesis of soluble (leachable) inorganic P (LIP) production by aerosol acidification. The EMS is unequivocally $\mathrm{P}$ limited with a molar nitrate-to-phosphate ratio of 28:1 in the deep water (Krom et al., 1991). Dry deposition is a major source of $\mathrm{P}$ to the basin and directly affects primary productivity in offshore areas (Krom et al., 2004). The Saharan desert is the principle source region of mineral aerosols reaching the central EMS and can interact with polluted airmasses from Europe and the Middle East. Size segregated aerosol samples were collected over a period of five years at the Finokalia station $\left(35^{\circ} 20^{\prime} \mathrm{N}, 25^{\circ} 40^{\prime} \mathrm{E}\right)$, a remote marine background site on Crete located $50 \mathrm{~m}$ inland and $230 \mathrm{~m}$ a.s.l. (Sciare et al., 2003). HYSPLIT back trajectories (www.arl.noaa.gov/ready/hysplit4.html) indicate that the air masses sampled at Finokalia originate from the marine boundary layer, Northern Africa, Europe, Asia Minor and the Middle East. Air masses from Europe, the former Soviet Republics and Asia Minor tend to exhibit the highest anthropogenic pollutant loadings (aerosol sulfates and nitrates), while the Mediterranean and Northern Africa typically yields cleaner air masses (Mihalopoulos et al., 1997). Hence, Saharan dust reaching Finokalia has experienced variable degrees of interaction with polluted air.

\subsection{Collection and chemical analysis of aerosol samples}

Aerosol samples were collected using a virtual impactor (VI; Loo and Cork, 1988). The VI was modified to divide particles into two size fractions: fine (aerodynamic particle diameter, $\left.D_{\mathrm{a}}<1.3 \mu \mathrm{m}\right)$ and coarse particles $\left(D_{\mathrm{a}}>1.3 \mu \mathrm{m}\right)$. The inlet preceding each VI has a cut-off size of $10 \mu \mathrm{m}$. The operational flow rate is $16.71 \mathrm{~min}^{-1}$, divided into 1.7 and
$15.01 \mathrm{~min}^{-1}$ minor and major flows, respectively. The average sampling time was two days (from 1 to 3 days). Polytetrafluoroethylene (PTFE) filters (Millipore Fluoropore; pore size $3.0 \mu \mathrm{m}$; diameter $47 \mathrm{~mm}$ ) were used for sampling.

Samples were pre- and post-weighed using a 6-digit microbalance (ATI-CAHN/CA27). The readability of the balance is $10 \mu \mathrm{g}$ with a precision of $40 \mu \mathrm{g}$ corresponding to mass concentration uncertainties of 0.86 and $0.77 \mu \mathrm{g} \mathrm{m}^{-3}$ for fine and coarse fractions, respectively. After weighing, the samples were stored in a freezer in Petrislides (Millipore Inc.). Samples were analyzed for water-soluble ions and LIP. One quarter of each PTFE filter was extracted using $20 \mathrm{ml}$ of nanopure water. The solutions obtained were analyzed by ion chromatography (IC) for anions $\left(\mathrm{Cl}^{-}, \mathrm{Br}^{-}, \mathrm{NO}_{3}^{-}, \mathrm{SO}_{4}^{2-}\right.$, $\mathrm{C}_{2} \mathrm{O}_{4}{ }^{2-}$ ) and cations $\left(\mathrm{Na}^{+}, \mathrm{NH}_{4}^{+}, \mathrm{K}^{+}, \mathrm{Mg}^{2+}\right.$ and $\mathrm{Ca}^{2+}$ ). Accuracy was determined by comparing results with certified WMO and DIONEX standards and was better than 5\% for all elements $(n=5)$. More details on the IC method are given in Bardouki et al. (2003). LIP was analyzed colorimetrically following Bardouki et al. (2003).

\subsection{Thermodynamic modelling of atmospheric samples}

The chemical composition, speciation and phase state of the aerosols collected on the filter samples were modelled using the ISORROPIA/ISORROPIA-II aerosol thermodynamic models (http://nenes.eas.gatech.edu/ISORROPIA; Nenes et al., 1998; Fountoukis et al., 2007). These models have been extensively evaluated against in-situ observations (e.g., Yu et al., 2005; Fountoukis et al., 2009), and are currently used for driving simulations in US, Asian and European global, regional and air quality models.

ISORROPIA/ISORROPIA-II simulates the composition of aerosol in equilibrium with the surrounding gas phase, including the transformations taking place when freshly emitted dust is mixed with acidic pollution. The model takes as input the amount of "aerosol precursor" sodium, potassium, ammonium (gas-phase $\mathrm{NH}_{3}$ plus aerosol ammonium), sulfate (in the form of neutral sulfate and bisulfate ions), magnesium, calcium, chloride (gas-phase $\mathrm{HCl}$ plus aerosol chloride), nitrate (gas-phase $\mathrm{HNO}_{3}$ plus aerosol nitrate), relative humidity and temperature. Based on this input, the model predicts at thermodynamic equilibrium the phases present in the aerosol particles (aqueous, solid, or both), the amount and chemical composition of each phase, and, the concentrations of semi-volatile species (i.e., $\mathrm{NH}_{3(\mathrm{~g})}, \mathrm{HNO}_{3(\mathrm{~g})}, \mathrm{HCl}_{(\mathrm{g})}$ ) in the gas phase.

Compositions are calculated by solving a system of equations derived from the equilibrium reactions and chemical potential of the species involved. The number of equations and iterations required is minimized by considering compositional "regimes"; because of this, ISORROPIA-II is considered one of the most computationally efficient thermodynamic equilibrium models available. Activity coefficients are calculated using pre-calculated lookup tables or 
a combination of Kusik-Meissner and Bromely models (the latter of which was used in this study). The amount of water contained within the aerosol is in equilibrium with the gas phase, so that the water activity must equal to the fractional relative humidity.

Predictions were carried out assuming that the aerosol particles are in equilibrium at an ambient relative humidity of $95 \%$, a temperature of $298 \mathrm{~K}$, and with compositions constrained from the observations. The equilibrium assumption applies well to submicron (fine) aerosol but may introduce errors when applied to coarse mode aerosol (e.g., Capaldo et al., 2000). Thermodynamic calculations are therefore carried out for all the fine aerosol samples, and for well-aged coarse aerosol samples (for which the carbonate buffer has been neutralized). The $\mathrm{pH}$ of the aerosol is predicted by ISORROPIA/ISORROPIA-II; the concentration of total dissolved $\mathrm{P}$ is calculated by dividing the measured LIP with the calculated aerosol liquid water content.

\subsection{Apatite solubility calculations}

Dissolution of apatite, $\mathrm{Ca}_{5}\left(\mathrm{PO}_{4}\right)_{3}(\mathrm{OH}, \mathrm{F}, \mathrm{Cl})$, is the primary source of mineral phosphorus in soils (Newman, 1995; Nezat et al, 2007). Reported solubility products for apatite minerals are highly variable, because of solid solution formation, incorporation of impurities (e.g., carbonate) and non-stoichiometric composition. Solubility calculations were carried out considering the pure end-member minerals hydroxyapatite (HAP) and the less-soluble fluorapatite (FAP) in $\mathrm{NaCl}$ solutions. The calculations provide a lower estimate of solubility, as the formation of aqueous phosphate complexes - in particular with magnesium will increase the solubility of an apatite mineral relative to that in a $\mathrm{NaCl}$ solution of the same ionic strength (Hershey et al., 1989). The incorporation of carbonate in the apatite structure further enhances the mineral solubility relative to that of the pure end-member phases (Jahnke, 1984). Dissolution of HAP and FAP is assumed to occur in a background electrolyte solution (i.e., containing no dissolved calcium, phosphate of fluoride initially) using the following solubility products for HAP and FAP at $25^{\circ} \mathrm{C}$ and 1 bar: $K_{\mathrm{HAP}}=\left(\mathrm{Ca}^{2+}\right)^{5}\left(\mathrm{HPO}_{4}^{2-}\right)^{3}\left(\mathrm{OH}^{-}\right) /\left(\mathrm{H}^{+}\right)^{3}$ $=10^{-20.47}$ and $K_{\mathrm{FAP}}=\left(\mathrm{Ca}^{2+}\right)^{5}\left(\mathrm{HPO}_{4}^{2-}\right)^{3}\left(\mathrm{~F}^{-}\right) /\left(\mathrm{H}^{+}\right)^{3}=$ $10^{-23.12}$ (Van Cappellen and Berner, 1991), where $(X)$ denotes the activity of ionic species $X$ in solution. The concentration of LIP, $m_{\mathrm{TP}}$, is related to that of $\mathrm{HPO}_{4}^{2-}$ via $m_{\mathrm{TP}}=m_{\mathrm{HPO}_{4}^{-2}}\left[{ }^{*} K_{3} /\left(\mathrm{H}^{+}\right)+1+\left(\mathrm{H}^{+}\right) /{ }^{*} K_{2}+\left(\mathrm{H}^{+}\right)^{2} /\right.$

${ }^{*} K_{1} * K_{2}$ ], where $m$ refers to aqueous concentrations in molal units, $\left(\mathrm{H}^{+}\right)$is the activity of hydronium ions in solution, and ${ }^{*} K_{1},{ }^{*} K_{2},{ }^{*} K_{3}$ are the conditional (stoichiometric) ionization constants of phosphoric acid. Combining the mineral solubility equilibria, the phosphoric acid dissociation equilibria and the mass balance constraints, $m_{\mathrm{Ca}} / 5=m_{\mathrm{TP}} / 3=$ $m_{\mathrm{HAP}}$ and $m_{\mathrm{Ca}} / 5=m_{\mathrm{TP}} / 3=m_{\mathrm{F}}=m_{\mathrm{HAP}}$, the total dissolved phosphate concentrations in equilibrium with HAP and FAP can be computed.

Representative solubility calculations were performed for HAP and FAP dissolving in pure electrolyte $(\mathrm{NaCl})$ solutions at $25^{\circ} \mathrm{C}$. The conditional ionization constants for phosphoric acid (measured up to $6 \mathrm{~m} \mathrm{NaCl}$ ) were taken from Hershey et al. (1989). The Pitzer ion interaction model was used to calculate the activity coefficients (Hershey et al., 1989; Millero and Schreiber, 1982). The latter is applicable up to $3-4 \mathrm{~m} \mathrm{NaCl}$, typical of electrolyte concentrations calculated using the ISORROPIA-II model predictions for aerosol at $\sim 95 \% \mathrm{RH}$.

\subsection{Results from Eastern Mediterranean aerosol analysis}

Under typical marine conditions (relative humidity 80$95 \%$ ), soluble electrolytes in the aerosol cause the uptake of water from the gas phase, forming an aqueous solution that is in contact with the insoluble components of the dust aerosol (Seinfeld and Pandis, 2006). This aerosol solution provides the medium for reacting and dissolving mineral-bound P. A proxy of the acidity of the aerosol aqueous phase is given by the soluble ion balance, $I_{\mathrm{b}}=2\left[\mathrm{SO}_{4}\right]+\left[\mathrm{H}_{2} \mathrm{PO}_{4}\right]+\left[\mathrm{NO}_{3}\right]$ $+[\mathrm{Cl}]-2[\mathrm{Ca}]-\left[\mathrm{NH}_{4}\right]-[\mathrm{Na}]-2[\mathrm{Mg}]-[\mathrm{K}]$ (where " $[X]$ " represents the measured concentration of species " $X$ " expressed in $\mu$ moles per $\mathrm{m}^{3}$ air, and $I_{\mathrm{b}}$ has units of $\mu$ greqs per $\mathrm{m}^{3}$ air, "greqs" being "gram-equivalents"). When $I_{\mathrm{b}}>0$, the aerosol tends to be acidic (as excess $\mathrm{H}^{+}$is required in the associated aqueous phase to neutralize the excess anions) and vice versa. The coarse (diameter $>1.3 \mu \mathrm{m}$ ) and fine (diameter $<1.3 \mu \mathrm{m}$ ) aerosol fractions exhibit distinct acidities (Fig. 1): $I_{\mathrm{b}}$ (and aerosol acidity) in the fine fraction is largely controlled by sulfate and in the coarse fraction by nitrate. When the aerosol is acidic $\left(I_{\mathrm{b}}>0\right)$, nitrate tends to partition to the gas-phase in the form of nitric acid (Meskhide et al., 2003). When the aerosol is neutral or alkaline $\left(I_{\mathrm{b}}<0\right)$, nitrate partitions to the aerosol phase, displacing chloride and carbonate ions (from seasalt and carbonate minerals) to the gas phase (in the form of $\mathrm{HCl}$ and $\mathrm{CO}_{2}$, respectively; Meskhidze et al., 2003). As expected, coarse particles contain relatively low sulfate levels, typical of marine background aerosols $(\sim 0.1-$ $1 \mu \mathrm{g} \mathrm{m}^{-3}$; Seinfeld and Pandis, 2006). Sulfate concentrations of fine particles were distinctly higher, indicative of continental pollution ( $\sim 1-10 \mu \mathrm{g} \mathrm{m}^{-3}$; Seinfeld and Pandis, 2006). Aerosol nitrate and sulfate concentrations no longer correlate with $I_{\mathrm{b}}$ when $I_{\mathrm{b}}<-0.05 \mu$ greqs $\mathrm{m}^{-3}$, probably because insufficient acid was present to titrate the carbonate buffer of dust.

For alkaline particles the measured mass ratio of soluble phosphorous to soluble calcium generally fell well below the P:Ca ratio of the mineral apatite (Fig. 2a). As aerosol acidity increased however, the soluble P:Ca ratios also increased and approached the value expected for the stoichiometric dissolution of apatite. The scatter in the data can in part be attributed 

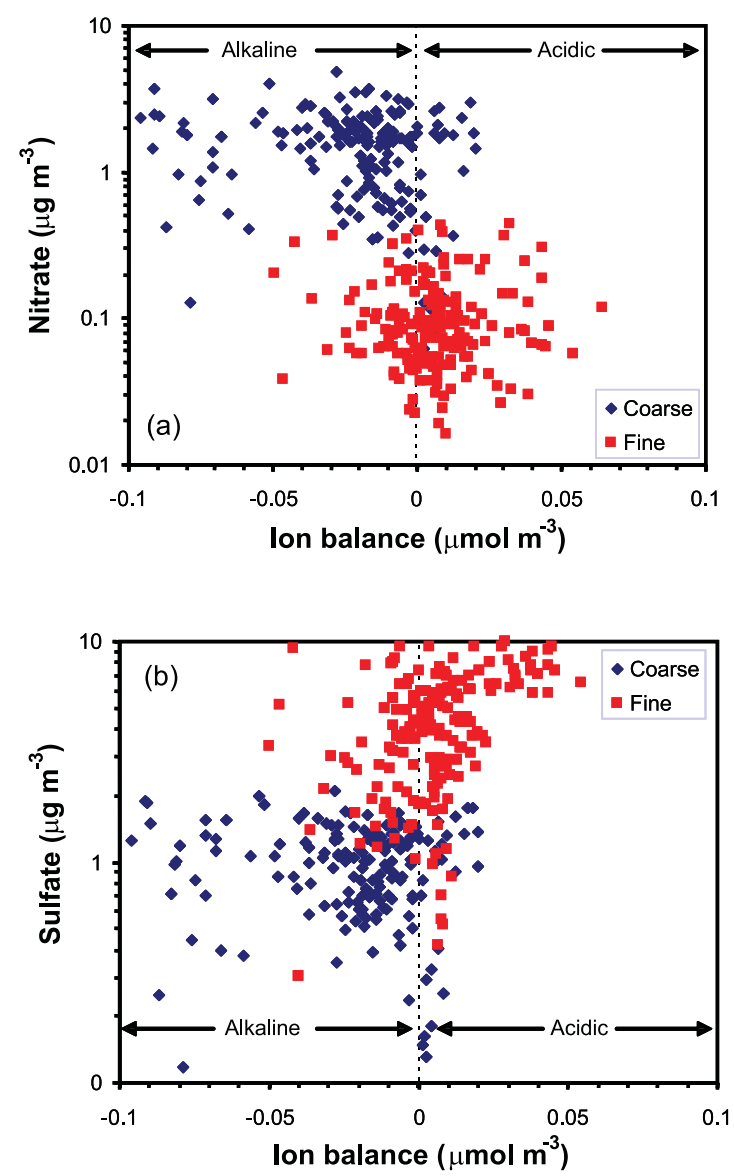

Fig. 1. Distributions of key acidic aerosol species in the Finokalia data set. Shown are the concentrations of (a) nitrate and (b) sulfate against the "ion balance", $I_{\mathrm{b}}$, calculated as $I_{\mathrm{b}}=2\left[\mathrm{SO}_{4}\right]+\left[\mathrm{H}_{2} \mathrm{PO}_{4}\right]$ $+\left[\mathrm{NO}_{3}\right]+[\mathrm{Cl}]-2[\mathrm{Ca}]-\left[\mathrm{NH}_{4}\right]-[\mathrm{Na}]-2[\mathrm{Mg}]-[\mathrm{K}]$, where " $[X]$ " represents the concentration of species " $X$ " in the aerosol sample, in mol $\mathrm{m}^{-3}$ air. Data for coarse and fine aerosol fractions are presented as blue and magenta symbols, respectively.

to chemical (and, hence, $\mathrm{pH}$ ) variability across particle size and time, which were averaged during aerosol collection (the $\mathrm{pH}$ of individual particles depends especially on their carbonate content which is known to be variable; samples collected over several days may also combine particles from somewhat different air masses). Nevertheless, the observed trend between the soluble P:Ca ratio and $I_{\mathrm{b}}$ is strongly consistent with acid mobilization of phosphate from apatite, the dominant form of $\mathrm{P}$ in Saharan dust (see below). Examining the data for periods where fires are at a minimum (OctoberMarch) results in a plot very similar to Fig. 2a (not shown); thus biogenic $\mathrm{P}$ from biomass burning is not the prime cause for the correlation between acidity and P:Ca.

In itself, $I_{\mathrm{b}}$ does not directly yield the exact $\mathrm{pH}$ level in the aerosol solution nor the amount of water available for dissolution of $\mathrm{P}$ from dust. Both can be estimated using ISORROPIA-II (Fountoukis and Nenes, 2007; Sect. 2.2). Using typical levels of relative humidity and
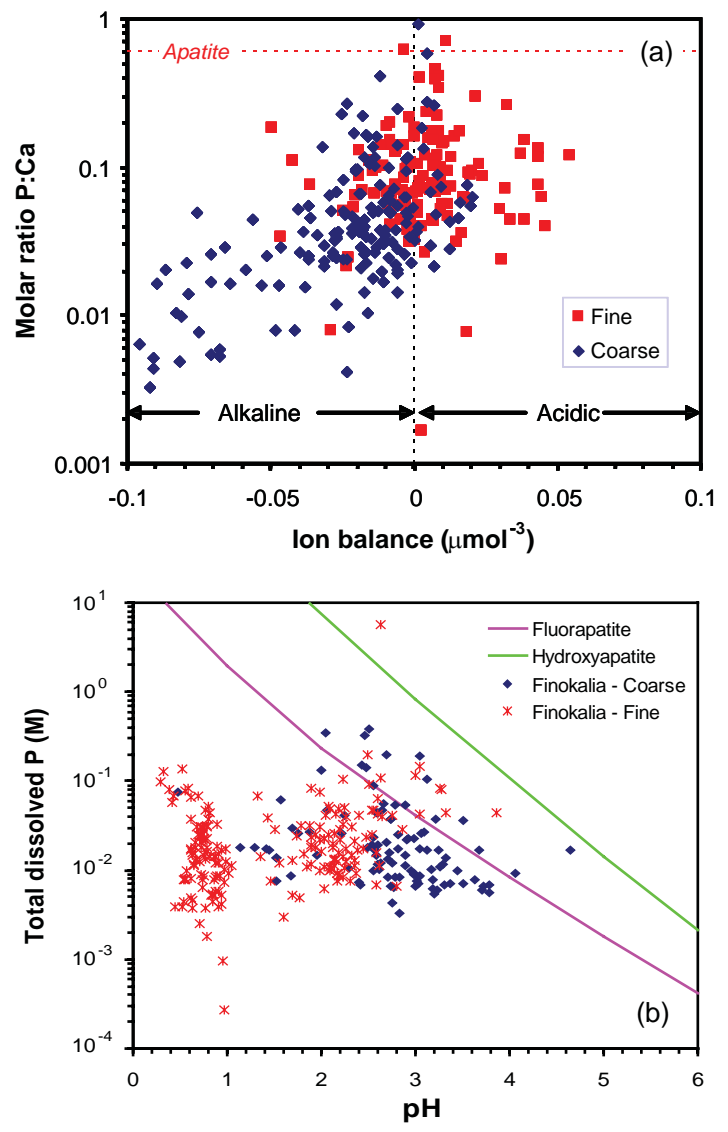

Fig. 2. (a) The molar ratio of LIP over $\mathrm{Ca}$ as a function of ion balance, $I_{\mathrm{b}}$. Fine fraction samples are shown with magenta symbols, coarse particles with blue symbols. Also shown is the P:Ca ratio for the mineral apatite. (b) Predicted concentration of total dissolved $\mathrm{P}$ against aerosol $\mathrm{pH}$. Predictions are carried out using the ISORROPIA-II thermodynamic model (Fountoukis and Nenes, 2007), assuming that the aerosol particles are at thermodynamic equilibrium with an ambient relative humidity $(\mathrm{RH})$ of $95 \%$, a temperature of $298 \mathrm{~K}$, and with aqueous compositions constrained from the observations. Also shown are the solubility lines for the end-member minerals fluorapatite, $\mathrm{Ca}_{5}\left(\mathrm{PO}_{4}\right)_{3} \mathrm{~F}$ and hydroxyapatite, $\mathrm{Ca}_{5}\left(\mathrm{PO}_{4}\right)_{3} \mathrm{OH}$. Repeating the calculations for lower $\mathrm{RH}$ decreases $\mathrm{pH}$, so that the aerosols become even more unsaturated with respect to the apatite minerals. For clarity only the solubility lines at ionic strength $3 \mathrm{~m}$ are plotted.

observed temperatures, the vast majority of fine aerosols at Finokalia exhibited low $\mathrm{pH}$ and were predicted to be highly undersaturated with respect to the most insoluble endmember apatite mineral, crystalline fluorapatite (Fig. 2b). Thus, thermodynamically, soil-derived apatite and ironbound $\mathrm{P}$ are expected to dissolve during aerosol acidification. Variations in relative humidity do not affect this model outcome. In fact, $\mathrm{pH}$ could substantially increase above 4 only if the aerosol particles were to reside in clouds and were activated into cloud droplets. Given however that atmospheric 
particles reside in subsaturated water vapor (non-cloud) conditions for most of their atmospheric residence time (Seinfeld and Pandis, 2006), the $\mathrm{pH}$ predictions and solubility considerations presented in Fig. $2 \mathrm{~b}$ reflect the most frequently occurring state in the atmosphere.

\section{Testing $\mathbf{P}$ mobilization hypothesis in the laboratory}

The Finokalia data and subsequent thermodynamic analysis suggest that acidification plays an important role in producing LIP. We tested the proposed mechanism by exposing Saharan soil and dust samples to $\mathrm{pH}$ levels consistent with the aerosol acidities derived from the Finokalia data. Soil samples were collected from two locations known to be major sources of modern Sahara dust: the Tibesti Mountains (hereafter Tibesti), and the Western Sahara (hereafter WS) (Brooks and Legrand, 2000; Prospero et al., 2002; Washington et al., 2009). The samples were wet-sieved to less than $20 \mu \mathrm{m}\left(\mathrm{PM}_{20}\right)$. We also generated $\mathrm{PM}_{10}$ (particulate matter less than $10 \mu \mathrm{m}$ ) from the re-suspended soils (called TibestiPM10 and WS-PM10 hereafter) without wet sieving. Details and chemical compositions of the samples are described in Shi et al. (2011a). In addition, two atmospheric Saharan dust samples were examined; they were collected at Bet Yanai, Israel, after dust storms on 10 May 2004 and on 29 March 2008 (hereafter BY1 and BY2, respectively). Prior to acid processing, the samples were characterised for the amounts of LIP, iron-bound mineral $\mathrm{P}(\mathrm{Fe}-\mathrm{P})$, calcium-bound mineral $\mathrm{P}$ (Ca-P), and organically-bound $\mathrm{P}$ (Org-P) using the SEDEX procedure (Ruttenberg, 1992). In order to simulate atmospheric processing, the mineral samples were placed in $\mathrm{pH} 2$ sulphuric acid for $24 \mathrm{~h}$.

\subsection{Phosphorus speciation of samples}

All samples were characterised for the amount of LIP, ironbound phosphorus (Fe-P), Ca-bound phosphorus, residual inorganic $\mathrm{P}$, and organic phosphorus (OP) using the SEDEX procedure (Ruttenberg et al., 2009):

- LIP: about $100 \mathrm{mg}$ of dust or soil samples were leached for $2 \mathrm{~h}$ in $10 \mathrm{ml}$ of $1 \mathrm{M} \mathrm{MgCl}_{2}$ solution adjusted to $\mathrm{pH} 8$ with $\mathrm{NaOH}$. The solutions were then filtered through $0.2 \mu \mathrm{m}$ pore size filters and the residues were treated with the same $\mathrm{MgCl}_{2}$ solution for another $2 \mathrm{~h}$ and then filtered. P in both extractions was added to obtain the LIP.

- Fe-P: $0.37 \mathrm{~g}$ sodium dithionite was added to the residue of previous extraction; $10 \mathrm{ml}$ of citrate buffer solution $\left(88.41 \mathrm{~g}^{-1}\right.$ trisodium citrate and $84.32 \mathrm{~g} \mathrm{l}^{-1}$ sodium bicarbonate) was then added to each sample. The solutions were shaken for $8 \mathrm{~h}$ at $25^{\circ} \mathrm{C}$. The samples were filtered through a $0.2 \mu \mathrm{m}$ pore size filter. Then $10 \mathrm{ml} \mathrm{MgCl}_{2}$ solution (same as above) was added to the residues and left for $2 \mathrm{~h}$. The samples were then filtered again through a $0.2 \mu \mathrm{m}$ pore size filter. The measured $\mathrm{P}$ was defined as Fe-P.

- Ca-bound-P: the residues were then treated with $10 \mathrm{ml}$ $1 \mathrm{M}$ sodium acetate solution buffered at $\mathrm{pH} 4$ with acetic acid for $6 \mathrm{~h}$ and then filtered. The residues were then leached with $\mathrm{MgCl}_{2}$ solutions (same as above) two times. The filtrates were mixed and then diluted for 5 times with double distilled water.

- Residual inorganic P: the residues were then treated with $10 \mathrm{ml} 1 \mathrm{M} \mathrm{HCl}$ for $16 \mathrm{~h}$ and then filtered. The Cabound-P and residual inorganic $\mathrm{P}$ added together was defined as Ca-P.

- Org-P: The residues were ashed at $550^{\circ} \mathrm{C}$ for $2 \mathrm{~h}$ and treated with $10 \mathrm{ml} 1 \mathrm{M} \mathrm{HCl}$ for $16 \mathrm{~h}$ and then filtered. The $\mathrm{P}$ was defined as OP.

$\mathrm{Ca}$-bound $\mathrm{P}$ and residual inorganic $\mathrm{P}$ are defined as $\mathrm{Ca}-$ $\mathrm{P}$. Fe-P + Ca-P are defined as total inorganic P. And the total inorganic $\mathrm{P}$ plus Org-P is total-P.

In addition to SEDEX, we also measured the seawater leachable P and total inorganic P (TIP) using independent method.

- Sea water leachable P: about $10 \mathrm{mg}$ of Tibesti, WS, BY1, or BY2 samples were put into $15 \mathrm{ml}$ tubes, and leached into seawater for $30 \mathrm{~h}$. The seawater was filtered through a $0.2 \mu \mathrm{m}$ pore size polycarbonate filter and was added with $50 \mu 11^{-1}$ of chloroform. After $30 \mathrm{~h}$, the samples were filtrated through a $0.2 \mu \mathrm{m}$ pore size Teflon filter. The dissolved phosphorus content of the seawater sample after filtration (and those of the blanks) was analyzed within an hour.

- TIP: about $10 \mathrm{mg}$ of Tibesti, Tibesti-PM10, WS, or WSPM10 samples were leached with $10 \mathrm{ml}$ of $1 \mathrm{M} \mathrm{HCl}$. The solution was left at room temperature overnight $(16 \mathrm{~h})$ with constant shaking. The solutions were then filtrated through $0.2 \mu \mathrm{m}$ pore size filters and the filtrates analysed for phosphorus.

Replicate analysis of Tibesti samples $(n=4)$ resulted in relative standard deviation of $14.2,9.4,10.6,3.0$ and $7.2 \%$ respectively for LIP, Fe-P, Ca-bound P, org-P and total-P. The measured $\mathrm{P}$ concentration in each extraction solution was corrected for the blanks.

TIP measured with SEDEX and with $1 \mathrm{M} \mathrm{HCl}$ only were 17.5 and $17.3 \mu \mathrm{mol} \mathrm{g}^{-1}$ in the Tibesti sample, and 18.6 and $18.5 \mu \mathrm{mol} \mathrm{g}^{-1}$ in the WS sample, respectively. TIP measured by $1 \mathrm{M} \mathrm{HCl}$ extractions in the Tibesti $\left(17.3 \mu \mathrm{mol} \mathrm{g}^{-1}\right)$ and WS $\left(18.5 \mu \mathrm{mol} \mathrm{g}^{-1}\right)$ were almost the same as that in TibestiPM10 $\left(17.5 \mu \mathrm{mol} \mathrm{g}^{-1}\right)$ and WS-PM10 $\left(18.2 \mu \mathrm{mol} \mathrm{g}^{-1}\right)$, respectively, suggesting that the $\mathrm{PM}_{20}$ is representative of the $\mathrm{PM}_{10}$. 
Table 1. Dust samples and simulated atmospheric processing results. All concentrations are given in $\mu$ mol per gram dry weight.

\begin{tabular}{lcccccccc}
\hline Sample & Seawater LIP & LIP & Fe-P & Ca-P & TIP & Org-P & Total-P & pH 2 LIP \\
\hline Tibesti & 0.3 & 0.5 & 2.6 & 14.4 & 17.5 & 4.5 & 21.9 & 16.7 \\
WS & 0.1 & 0.7 & 2.5 & 15.3 & 18.4 & 2.8 & 21.3 & 15.8 \\
BY1 & 0.9 & 1.3 & 5.3 & 24.8 & 31.3 & 2.0 & 33.4 & 25.4 \\
BY2 & 4.0 & 3.2 & 8.1 & 22.0 & 33.3 & 5.6 & 38.8 & 31.8 \\
BYD1* & & 1.9 & 5.3 & 18.0 & 25.2 & 3.2 & 28.4 & \\
\hline
\end{tabular}

* Data from Eijsink et al. (2000).
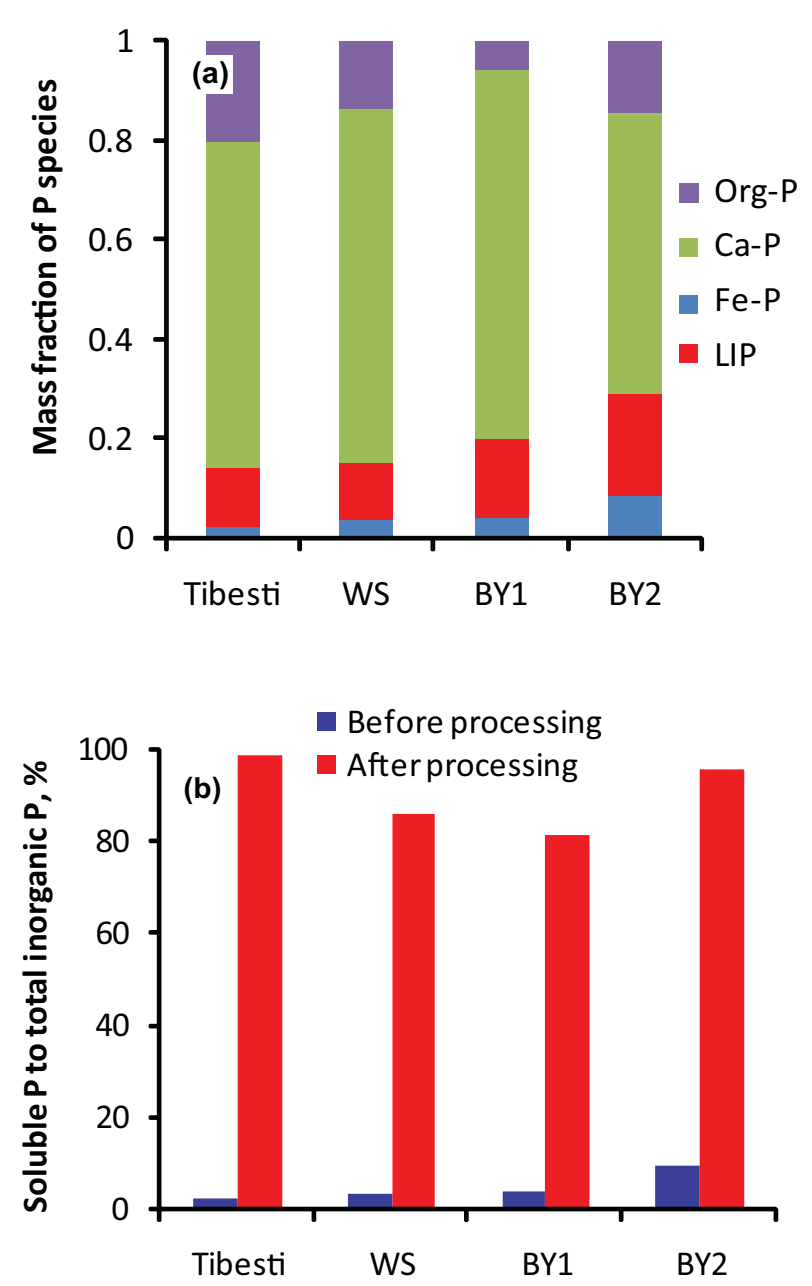

Fig. 3. (a) Phosphorus speciation in Saharan soil and natural Saharan dust. (b) The change in soluble $\mathrm{P}$ to total inorganic $\mathrm{P}$ as a result of simulated atmospheric processing at $\mathrm{pH} 2$ for $24 \mathrm{~h}$.

\subsection{Laboratory simulated atmospheric acid processing and analysis}

About $10 \mathrm{mg}$ of Tibesti-PM20, Tibesti-PM10, WS-PM20, WS-PM10, BY1 or BY2 were added to $10 \mathrm{ml} \mathrm{pH} 2$ sulfuric acid solution, respectively. The samples were stirred continuously for $24 \mathrm{~h}$ at room temperature. At the end of each experiment, the samples were filtered through $0.2 \mu \mathrm{m}$ pore size Teflon filters and the solutions taken for subsequent $\mathrm{P}$ analysis.

All dissolved phosphorus determinations were carried out by the molybdate-blue method according to Strickland and Parsons (1972) for sea water extractions and Aspila et al. (1976) for all other extractions.

\subsection{Interpreting laboratory acidification experiments}

In agreement with previous studies (Singer et al., 2004; Eijsink et al., 2000), we found that Ca-P was by far the dominant form of $\mathrm{P}$ in Saharan soil dust ( $>50 \%$ ) while iron-bound $\mathrm{P}$ represents less than $20 \%$ (Table 1). LIP represented only 3-10\% of total inorganic P in Saharan soil samples and dry fallout collected during Sahara dust storms (Fig. 3a). Acid treatment of the samples caused a 10-40 times increase of their soluble P fraction of total inorganic P (Fig. 3b). In the Saharan soil and dust samples, $81-96 \%$ of the total inorganic $\mathrm{P}$ was released to solution following the acid treatment. Mass balance considerations show that this soluble $\mathrm{P}$ was derived from both apatite and iron-bound P. The experimental results overall showed that significant fractions of $\mathrm{P}$ present in Saharan dust can be solubilised by acidification in the atmosphere. Upon deposition of the aerosols at the sea surface, the solubilised $\mathrm{P}$ will remain in solution and be available for direct uptake by phytoplankton (Herut et al., 2005). This is in contrast to soluble iron which precipitates as Fe oxyhydroxide nanoparticles under the alkaline and oxygenated conditions in surface waters (Shi et al., 2009).

\section{Conclusions and implications}

In recent years, it has become apparent that $\mathrm{P}$ (co-)limitation in the ocean is more widespread than previously thought (Elser et al., 2007; Paytan et al., 2007). In view of this, our results suggest that variations in acid gas emissions by natural and anthropogenic sources may play an important role in regulating marine primary productivity and autotroph nutrient limitation through their effect on the fraction of soluble $\mathrm{P}$ in mineral aerosols. While atmospheric pollution is widely 
acknowledged as a major source of new nitrogen $(\mathrm{N})$ to the global ocean (Duce et al., 2008) we propose that anthropogenic $\mathrm{SO}_{2}$ and $\mathrm{NO}_{\mathrm{x}}$ emissions may also increase the input of bioavailable $\mathrm{P}$. Because primary production in marine environments often exhibits a positive synergistic response to simultaneous enrichments in $\mathrm{N}$ and $\mathrm{P}$ (Elser et al., 2007), $\mathrm{SO}_{2}$ and $\mathrm{NO}_{\mathrm{x}}$ emissions have the potential to significantly enhance marine primary production, particularly in offshore areas of the ocean where large amounts of mineral aerosol interact with polluted air masses, such as in the EMS, the NW Atlantic or the western Pacific. Similar processes are known to affect the fraction of bioavailable $\mathrm{Fe}$ in mineral dust (e.g. Shi et al., 2009, 2011b). The interaction between these two elements in atmospheric aerosols will no doubt be the subject of future research. In the extreme case that $100 \%$ of atmospheric $\mathrm{P}$ deposition were bioavailable it could, assuming $\mathrm{P}$ limitation, account for a yearly global oceanic uptake of $\mathrm{CO}_{2}$ of $264 \mathrm{~T}$ moles, that is, more than three times the current $\mathrm{CO}_{2}$ emissions from fossil fuel burning (Mahowald et al., 2008). As shown here, even if total P deposition remains constant, the soluble fraction can significantly increase as a result of aerosol acidification (Fig. 3b).

Soluble $\mathrm{P}$ production by aerosol acidification also helps explain the proposed link between episodes of massive volcanism and global ocean anoxia in the geological past (Adams et al., 2010). On geological time scales, ocean productivity is $\mathrm{P}$ limited because the marine biosphere can accommodate any long-term nitrogen deficiency by increasing nitrogen fixation (Paytan et al., 2007; Tyrell, 1999). A massive release of acidic gases by volcanic activity would then dramatically increase the acid processing of aerosols in the atmosphere (as well as enhance chemical weathering on land). The resulting increase in bioavailable $\mathrm{P}$ supply to the oceans would trigger a major increase in primary productivity, which in turn would enhance the supply of organic carbon to the deep ocean eventually resulting in widespread ocean anoxia with its distinctive chemical and isotopic signatures (Adams et al., 2010).

On shorter time scales, the potential also exists for a phytoplankton-mediated feedback between aerosol acidification and ocean productivity. Under conditions of nutrient stress, marine phytoplankton increase emissions of dimethyl sulfide (DMS) from the surface ocean (Sunda et al., 2002). The DMS then converts to sulphuric and methane-sulfonic acid in the atmosphere (Meskhidze et al., 2003; Barnes et al., 2006). Based on the proposed hypothesis, this would in turn increase atmospheric deposition of bioavailable $\mathrm{P}$, hence alleviating the initial nutrient stress. It would thus appear that atmospheric processes could play a far greater role in the biogeochemical cycling of phosphorus than is currently acknowledged.
Acknowledgements. A. Nenes acknowledges support by NASA ACMAP and a NSF CAREER award. Z. Shi was supported in this work by NERC (NE/E011470/1, PI: Krom). The ideas in this paper developed while M.D. Krom was on sabbatical leave at the Georgia Institute of Technology.

Edited by: M. C. Facchini

\section{References}

Adams, D. D., Hurtgen, M. T., and Sageman, B. B.: Volcanic triggering of a biogeochemical cascade during Oceanic Anoxic Event 2, Nat. Geosci., 3, 201-204, 2010.

Aspila, K. I., Agemian, H., Chau, and A. S. Y.: A semi-automated method for the determination of inorganic, organic and total phosphate in sediments, Analyst, 101, 187-197, 1976.

Atlas, E. and Pytkowicz, R. M.: Solubility behavior of apatites in seawater, Limnol. Oceanogr., 22, 290-300, 1997.

Baker, A. R., Jickells, T. D., Biswas, K. F., Weston, K., and French, M.: Nutrients in atmospheric aerosol particles along the Atlantic Meridional Transect, Deep Sea Res., 53(14-16), 1706-1719, 2006.

Bardouki, H., Liakakou, H., Economou, C., Sciare, J., Smolik, J., Zdimal, V., Eleftheriadis, K., Lazaridis, M., Dye, C., and Mihalopoulos, N.: Chemical composition of size resolved atmospheric aerosols in the eastern Mediterranean during summer and winter, Atmos. Environ., 37, 195-208, 2003.

Barnes, I., Hjorth, J., and Mihalopoulos, N.: Dimethyl sulfide and dimethyl sulfoxide and their oxidation in the atmosphere, Chem. Rev., 106, 940-975, 2006.

Brooks, N. and Legrand, M.: Dust variability over northern Africa and rainfall in the Sahel, in: Linking Climate Change to Land Surface Change, edited by: McLaren, S., D. Kniveton Kluwer Acad., Dordrecht, 1-26, 2002.

Capaldo, K. P., Pilinis, C., and Pandis, S. N.: A computationally efficient hybrid approach for dynamic gas/aerosol transfer in air quality models, Atmos. Environ., 34, 3617-3627, 2000.

Duce, R. A., LaRoche, J., Altieri, K., Arrigo, K. R., Baker, A. R., Capone, D. G., Cornell, S., Dentener, F., Galloway, J., Ganeshram, R. S., Geider, R. J., Jickells, T., Kuypers, M. M., Langlois, R., Liss, P. S., Liu, S. M., Middelburg, J. J., Moore, C. M., Nickovic, S., Oschlies, A., Pedersen, T., Prospero, J., Schlitzer, R., Seitzinger, S., Sorensen, L. L., Uematsu, M., Ulloa, O., Voss, M., Ward, B., and Zamora, L.: Impacts of atmospheric nitrogen on the open ocean, Science, 320, 893-897, 2008.

Eijsink, L. M., Krom, M. D., and Herut, B.: Speciation and burial flux of phosphorus in the surface sediments of the eastern Mediterranean, Am. J. Sci., 300(6), 483-504, 2000.

Elser, J. J., Bracken, M. E. S., Cleland, E. E., Gruner, D. S., Harpole, W. S., Hillebrand, H., Ngai, J. T., Seabloom, E. W., Shurin, J. B., and Smith, J. E.: Global analysis of nitrogen and phosphorus limitation of primary producers in freshwater, marine and terrestrial ecosystems, Ecol. Lett., 10, 1135-1142, 2007.

Fountoukis, C. and Nenes, A.: ISORROPIA II: a computationally efficient thermodynamic equilibrium model for $\mathrm{K}^{+}-\mathrm{Ca}^{2+}$ $-\mathrm{Mg}^{2+}-\mathrm{NH}_{4}^{+}-\mathrm{Na}^{+}-\mathrm{SO}_{4}^{2-}-\mathrm{NO}_{3}-\mathrm{Cl}^{-}-\mathrm{H}_{2} \mathrm{O}$ aerosols, Atmos. Chem. Phys., 7, 4639-4659, doi:10.5194/acp-7-4639-2007, 2007. 
Fountoukis, C., Nenes, A., Sullivan, A., Weber, R., Van Reken, T., Fischer, M., Matas, E., Moya, M., Farmer, D., and Cohen, R. C.: Thermodynamic characterization of Mexico City aerosol during MILAGRO 2006, Atmos. Chem. Phys., 9, 2141-2156, doi:10.5194/acp-9-2141-2009, 2009.

Hershey, J. P., Fernandez, M., and Millero, F. J.: The dissociation of phosphoric acid in $\mathrm{NaCl}$ and $\mathrm{NaMgCl}$ solutions at $25^{\circ} \mathrm{C}, \mathrm{J}$. Solution Chem., 18, 875-891, 1989.

Herut, B., Zohary, T., Krom, M. D., Mantoura, R. F. C., Pitta, P., Psarra, S., Rassoulzadegan, F., Tanaka, T., and Thingstad, T. F.: Response of East Mediterranean surface water to Sahara dust: On-board microcosm experiment and field observations, DeepSea Res. II, 52, 3024-3040, 2005.

Howarth, R. W.: Nutrient limitation of net primary production in marine ecosystems, Ann. Rev. Ecol., 19, 89-110, 1988.

Jahnke, R. A.: The synthesis and solubility of carbonate fluorapatite, Am. J. Sci., 284, 58-78, 1984.

Krom, M. D., Brenner, S., Kress, N., and Gordon, N. L. I.: Phosphorus limitation of Primary Productivity in the E. Mediterranean sea, Limnol. Ocean.,36(3), 424-432, 1991.

Krom, M. D., Herut, B., and Mantoura, R. F. C.: Nutrient budget for the Eastern Mediterranean: Implications for P limitation, Limnol. Ocean., 49, 1582-1592, 2004.

Loo, B. W. and Cork, C. P.: Development of high efficiency virtual impactor, Aerosol Sci. Technol., 9, 167-170, 1988.

Mahowald, N., Jickells, T. D., Baker, A. R., Artaxo, P., BenitezNelson, C. R., Bergametti, G., Bond, T. C., Chen, Y., Cohen, D. D., Herut, B., Kubilay, N., Losno, R., Luo, C., Maenhaut, W., McGee, K. A., Okin, G. S., Siefert, R. L., and Tsukuda, S.: Global distribution of atmospheric phosphorus sources, concentrations and deposition rates, and anthropogenic impacts, Global Biogeochem. Cy., 22, GB4026, doi:10.1029/2008GB003240, 2008.

Meskhidze, N., Chameides, W. L., Nenes, A., and Chen, G.: Iron mobilization in mineral dust: Can anthropogenic $\mathrm{SO}_{2}$ emissions affect ocean productivity?, Geophys. Res. Lett., 30(21), 2085, doi:10.1029/2003GL018035, 2003.

Mihalopoulos, N., Stephanou, E., Pilitsidis, S., Kanakidou, M., and Bousquet, P.: Atmospheric aerosol composition above the Eastern Mediterranean region, Tellus, 49B, 314-326, 1997.

Millero, F. J. and Schreiber, D. R.: Use of the ion pairing model to estimate activity coefficients of the ionic components of natural waters, Am. J. Sci., 282, 1508-1540, 1982.

Nenes, A., Pilinis, C., and Pandis, S. N.: ISORROPIA: A New Thermodynamic Model for Multiphase Multicomponent Inorganic Aerosols, Aquat. Geochem., 4, 123-152, 1998.

Newman, E. I.: Phosphorus inputs to terrestrial ecosystems, J. Ecol., 83, 713-726, 1995.

Nezat, C. A., Blum, J. D., Yanai, R. D., and Hamburg, S. P.: A sequential extraction to determine the distribution of apatite in granitoid soil mineral pools with application to weathering at the Hubbard Brook Experimental Forest, NH, USA, Appl. Geochem., 22, 2406-2421, 2007.

Paytan, A. and McLaughlin, K.: The oceanic phosphorus cycle, Chem. Rev., 107, 563-576, 2007.

Prospero, J. M., Ginoux, P., Torres, O., Nicholson, S. E., and Gill, T. E.: Environmental characterization of global sources of atmospheric soil dust dandified with the NIMBUS 7 Total Ozone Mapping Spectrometer (TOMS) absorbing aerosol product, Rev.
Geophys., 40(1), 1002, doi:10.1029/2000RG000095, 2002.

Ruttenberg, K.: Development of a sequential extraction method for different forms of phosphorus in marine sediments, Limnol. Oceanogr., 37, 1462-1482, 1992.

Sciare, J., Bardouki, H., Moulin, C., and Mihalopoulos, N.: Aerosol sources and their contribution to the chemical composition of aerosols in the Eastern Mediterranean Sea during summertime, Atmos. Chem. Phys., 3, 291-302, doi:10.5194/acp-3-291-2003, 2003.

Seinfeld, J. H. and Pandis, S. N.: Atmospheric chemistry and physics: from air pollution to climate change, John Wiley \& Sons Inc, New York, 2006.

Shi, Z. B., Krom, M. D., Bonneville, S., Baker, A. R., Jickells, T. D., and Benning, L. G.: Formation of iron nanoparticles and increase in iron reactivity in the mineral dust during simulated cloud processing, Environ. Sci. Technol., 43, 6592-6596, 2009.

Shi, Z., Krom, M., Bonneville, S., Baker, A., Bristow, C., Drake, N., Mann, G., Carslaw, K., McQuaid, J., Jickells, T., and Benning, L.: Chemical weathering controls Fe solubility in the dust deposited to the ocean, Global Biogeochem. Cy., 25, GB2010, doi:10.1029/2010GB003837, 2011a.

Shi, Z., Bonneville, S., Krom, M. D., Carslaw, K. S., Jickells, T. D., Baker, A. R., and Benning, L. G.: Iron dissolution kinetics of mineral dust at low $\mathrm{pH}$ during simulated atmospheric processing, Atmos. Chem. Phys., 11, 995-1007, doi:10.5194/acp11-995-2011, $2011 b$.

Singer, A., Dultz, S., and Argaman, E.: Properties of the nonsoluble fractions of suspended dust over the Dead Sea, tmos. Environ. 38, 1745-1753, 2004.

Spokes, J. L, Jickells, T. D., and Lim, B.: Solubilisation of aerosol trace metals by cloud processing: A laboratory study, Geochim. Cosmochim. Acta, 58, 3281-3287, 1994.

Stumm, W. and Morgan, J. J.: Aquatic Chemistry, WileyInterscience, New York, 1996.

Strickland, J. D. H. and Parsons, T. R.: A practical handbook of sea-water analysis, J. Fish. Res. Bd. Canada, 167, 1-311, 1972.

Sunda, W., Kieber, D. J., Kiene, R. P., and Huntsman, S.: An antioxidant function for DMSP and DMS in marine algae, Nature, 418, 317-320, 2002.

Tyrell, T.: The relative influences of nitrogen and phosphorus on oceanic primary production, Nature, 400, 525-531, 1999.

Van Cappellen, P. and Berner, R. A.: Fluorapatite crystal growth from modified seawater solutions, Geochim. Cosmochim. Acta, 55, 1219-1234, 1991.

Washington, R., Bouet, C., Cautenet, G., Mackenzie, E., Ashpole, I., Engelstaedter, S., Lizcano, G., Henerson, G. M., Schepanski, K., and Tegen, I.: Dust as a tipping element: The Bodèlè Depression, Chad, Proc. Natl. Acad. Sci., 106(49), 20564-20571, doi:10.1073/pnas.0711850106, 2009.

Yu, S., Dennis, R., Roselle, S., Nenes, A., Walker, J. T., Eder, B., Schere, K., Swall, J., and Robarge, W.: An assessment of the ability of 3-D air quality models with current thermodynamic equilibrium models to predict aerosol $\mathrm{NO}_{3}^{-}$, J. Geophys. Res., 110, D07S13, doi:10.1029/2004JD004718, 2005. 